\title{
KEDUDUKAN OTORITAS JASA KEUANGAN DALAM PENGAWASAN BAITUL MAAL WAT TAMWIL
}

\author{
Sunarto Sunarto \\ Magister Hukum Universitas Semarang
}

\begin{abstract}
ABSTRAK
Tujuan dan maksud dari penelitian ini adalah untuk mengetahui kedudukan otoritas jasa keuangan dalam pengawasan Baitul Maal Wat Tamwil. Kedudukan OJK diorientasikan dengan tujuan meningkatkan dan memelihara kepercayaan publik di bidang jasa keuangan, menegakkan peraturan perundang-undangan di bidang jasa keuangan, meningkatkan pemahaman public mengenai bidang jasa keuangan; dan Melindungi kepentingan konsumen jasa keuangan Pola dan mekanisme yang dilakukan otoritas jasa keuangan pada lembaga keuangan mikro sangat lemah karena Fungsi pengawasan sebatas koordinasi, dan berkenaan dengan kegiatan usaha yang berdasarkan prinsip pun demikian. Disinilah peran OJK untuk ditingkatkan kapasitasnya dalam pengawasan BMT. Metode yang digunakan dalam penelitian ini adalah yuridis normatif. Kewenangan OJK melakukan pengawasan lebih esensial dibanding lembaga lain. OJK dalam praktiknya sangat mampu menjalankan perananya sesuai dengan ketentuan yang ada dan secara kelembagaan, Otoritas Jasa Keuangan berada di luar Pemerintah, yang dimaknai bahwa Otoritas Jasa Keuangan tidak menjadi bagian dari kekuasaan Pemerintah. Namun, tidak menutup kemungkinan adanya unsur-unsur perwakilan Pemerintah karena pada hakikatnya Otoritas Jasa Keuangan merupakan otoritas di sektor jasa keuangan yang memiliki relasi dan keterkaitan yang kuat dengan otoritas lain, dalam hal ini otoritas fiskal dan moneter. Perubahan regulasi bahwa OJK dapat menjalankan peran sebagai lembaga pengawas tentunya sangat penting untuk dilakukan. Selain itu harmonisasi peraturan untuk mengarahkan OJK sebagai salah satu lembaga independent pengawas Jasa keuangan sangat dibutuhkan agar dikemudian hari posisi OJK dapat menjadi kontribusi nyata pada pelaksanaan sistem keuangan pada BMT.
\end{abstract}

Kata kunci : jasa keuangan; pengawasan; baitul maal wat tamwil 
e-ISSN : $2621-4105$

\title{
THE STANDING OF INSTITUTION OF FINANCE SERVICE AUTORITIES IN TERM OF SUPERINTENDENCE BAITUL MAAL WAT TAMWIL
}

\author{
Sukadi Suratman, Muhammad Junaidi \\ Master of Law, University of Semarang
}

\begin{abstract}
The purpose and purpose of this study is to determine the position of the financial services authority in the supervision of Baitul Maal Wat Tamwil. Finance Service Autorities standing oriented with purpose for improve and keep public's trust in term of service finance, enforce the legislation in the field finance service, increase the public's comprehension about finance service; protect the consument interest of finance sevice. Pattern and mechanism that have been done by Finance Service Autorities to micro finance foundation very weak because function of superintendence limited coordination. Here the role of Finance Service Autorities for be increased its capacity in term of baitul mall wat tamwil's superintendence. Competency of Finance Service Autorities do superintendence more essential than the another institution.The method that used in this research is normative juridical..In the practice's of Finance Service Autorities very adequate for perform his role according to valid provisio, Finance Service Autorities is out of government, that interpreted Finance Service Autorities is not part of government authorities. The amandement of regulation that Finance Service Autorities could perform the role as superintendence institution is very important for done.
\end{abstract}

\section{Keyword : Finance service; superintendent; baitul maal wat tamwil}


e-ISSN : 2621-4105

\section{A. PENDAHULUAN}

Pada orde reformasi tahun 1998, Undang-Undang Perbankan (UU No. 7 Tahun 1992) dilakukan perubahan dengan UU No. 10 Tahun 1998 tentang perbankan. Berbeda dengan UU No. 7 Tahun 1992 yang tidak mengatur secara pasti perbankan syariah, ketentuan-ketentuan mengenai perbankan syariah dalam UU No. 10 Tahun 1998 lebih lengkap (exhaustive) dan sangat membantu perkembangan perbankan syariah di Indonesia. Undang-Undang No. 10 Tahun 1998 secara tegas menggunakan kata bank syariah dan mengatur secara jelas bahwa bank, baik bank umum dan BPR, dapat beroperasi dan melakukan pembiayaan berdasarkan pada prinsip syariah. (lihat Pasal 1 butir 12, Pasal 7 huruf c, Pasal 8 ayat (1 \& 2), Pasal 11 ayat (1) \& (4a), Pasal 13, Pasal 29 ayat (3) dan Pasal 37 ayat (1) huruf c).

Adapun yang dimaksud dengan prinsip syariah, menurut Pasal 1 butir 13, adalah aturan perjanjian berdasarkan hukum Islam antara bank dan pihak lain untuk penyimpanan dana dan atau pembiyaan kegiatan usaha, atau kegiatan lainnya yang dinyatakan sesuai dengan syariah, antara lain pembiayaan berdasarkan prinsip bagi hasil (mudharabah), pembiayaan berdasarkan prinsip pernyertaan modal (musharakah), prinsip jual beli barang dengan memperoleh keuntungan (murabah), atau pembiayaan barang modal berdasarkan prinsip sewa murni tanpa pilihan (ijarah), atau dengan adanya pilihan pemindahan kepemilikan atas barang yang disewa dari pihak bank oleh pihak lain (ijarah wa iqtina). Ketentuan di atas menunjukkan perluasanan eksistensi bank syariah dalam melaksanakan kegiatannya, di mana dalam UU sebelumnya hal tersebut tidak diatur secara jelas.

Implementasi terhadap prinsip-prinsip syariah tersebut tidak terkecuali dalam penerapan baitul maal wa tamwil (BMT). BMT merupakan lembaga keuangan yang memiliki dua unit usaha sekaligus. Baitul tamwil bergiat mengembangkan usahausaha produktif dan investasi dalam meningkatkan kualitas kegiatan pengusaha kecilbawah dengan mendorong kegiatan menabung dan menunjang pembiayaan ekonomi, sedangkan baitul maal menerima titipan zakat, infaq dan sodaqah serta menjalankannya sesuai dengan peraturan dan amanahnya. 
e-ISSN : $2621-4105$

Keberadaan baitul maal wa tamwil (BMT) sebagai salah satu perintis lembaga keuangan dengan prinsip syariah di Indonesia, dimulai dari ide para aktivis Masjid Salman ITB Bandung yang mendirikan Koperasi Jasa Keahlian Teknosa pada 1980. Koperasi inilah yang menjadi cikal bakal BMT yang berdiri pada tahun 1984. Konsep awal BMT dimulai dari tesis syar'iyah, “Dapatkah konsep Maal dan Tamwil digabungkan menjadi satu?", satu sama lain saling melengkapi. Maal yang diambil dari ZIS dijadikan pengaman pembiayaan bagi 8 golongan yang berhak menerima Zakat (ashnaf). Singkatnya, dana ZIS digunakan sebagai dana produktif. Sedangkan Tamwil, murni bisnis yang hitungannya dan akadnya jelas. Kewajiban dan hak-haknya, yang digunakan secara bisnis murni ${ }^{1}$.

Baitul Maal Wat - Tamwil adalah salah satu lembaga keuangan mikro yang memiliki angka pertumbuhan sangat pesat dari tahun ke tahun, sebagaimana disampaikan oleh Joelarso, Ketua Umum Dewan Pimpinan Pusat Perhimpunan BMT Indonesia, "hingga akhir 2012 ini, terdapat 3.900 BMT. Sebanyak 206 di antaranya bergabung dalam asosiasi BMT seluruh Indonesia. Pada tahun 2005, seluruh aset 96 BMT yang menjadi anggota asosiasi mencapai Rp 364 miliar. Pada 2006, aset tumbuh menjadi Rp 458 miliar, dan hingga akhir 2011 jumlah aset mencapai Rp 3,6 triliun dari 206 BMT yang bergabung di asosiasi". Dalam perkembangannya, di tahun 2013, angka pertumbuhan BMT sudah mencapai lebih dari 5500 BMT yang tersebar di seluruh Indonesia. Sebagai bagian dari LKM yang terus bertumbuh, sebagaimana data yang disampaikan oleh Kepala Eksekutif Pengawas Industri Keuangan Non Bank Otoritas Jasa Keuangan Firdaus Djaelani, yang memperkirakan bahwa saat ini jumlah LKM di Indonesia sekitar 567 ribu sampai 600 ribu unit. Ini menunjukkan bahwa lembaga keuangan mikro adalah lembaga keuangan yang sangat dibutuhkan oleh masyarakat kecil, khususnya di daerah-daerah untuk menunjang dan mendukung

\footnotetext{
${ }^{1}$ https://id.wikipedia.org/wiki/Baitul_Maal_wa_Tam wil, diunduh pada 12 November 2017
} 
e-ISSN : 2621-4105

pertumbuhan ekonomi kerakyatan, terutama masyarakat berpenghasilan rendah yang selama ini tidak terjangkau oleh layanan perbankan².

Apabila dianalisis lebih mendalam, eksistensi kelembagaan atas status badan hukum BMT sebagai Koperasi Jasa Keuangan Syariah (KJKS) yang tunduk kepada UU No. 25 Tahun 1992 tentang Perkoperasian dan telah diubah menjadi UndangUndang No. 17 Tahun 2012 tentang Perkoperasian yang selanjutnya telah dibatalkan oleh Mahkamah Konstitusi dan kembali pada undang-undang yang lama yaitu Undang-Undang No. 25 Tahun 1992 tentang Perkoperasian, masih belum mampu mengakomodir keberadaan BMT sebagai salah satu lembaga keuangan yang melayani kebutuhan masyarakat. Hal ini disebabkan, BMT berbeda dengan koperasi jenis koperasi pada umumnya, karena BMT dilaksanakan dengan prinsip syariah yang berbeda dengan koperasi konvensional dan dalam BMT terdapat misi sosial sebagai Baitul Maal yang tidak bisa dipaksakan tunduk sepenuhnya pada undangundang koperasi ${ }^{3}$.

Namun pada sisi lain, dalam praktiknya Pengawasan yang tercakup dalam tugas Otoritas Jasa Keuangan (OJK) tidak termasuk pada lembaga keuangan berbentuk koperasi, lembaga keuangan mikro, dan Baitul Mal Wa Tamwil (lembaga keuangan berbasis syariah). OJK hanya ditugasi untuk mengawasi bank, bank perkreditan rakyat, dan lembaga keuangan bukan bank. Padahal kewenangan OJK sangatlah diharapkan mampu menjadikan iklim stbil pelaksanaan sistem keuangan syaraiah yang dijalankan oleh Baitul Mal Wa Tamwil (lembaga keuangan berbasis syariah).

OJK sendiri dalam Peraturan Otoritas Jasa Keuangan Nomor /POJK.05/2014 Tentang Penyelenggaraan Usaha Lembaga Keuangan Mikro memberikan deskripsi yang jelas terhadap kapasitas OJK sebagai pengawas. Akan tetapi mengingat kedudukan tersebut tidak jelas secara tafsir konstitusional, maka menjadikan

${ }^{2}$ Novita Dewi Mashyitoh, Analisis normatif undang-undang no. 1 tahun 2013 tentang lembaga keuangan mikro ( $\mathrm{km}$ ) atas status badan hukum dan pengawasan baitul maal wat tamwil (BMT), Jurnal economica, Volume V/Edisi 2/Oktober 201421

${ }^{3}$ lbid., hlm 27 
e-ISSN : 2621-4105

kepasitas OJK tidak mendapatkan tempat dalam pengawasan sistem keuangan oleh lembaga Mikro seperti BMT.

\section{B. PERMASALAHAN}

Fokus permasalahan yang dibahas dalam penelitian ini adalah sebagai berikut

1. Bagaimana kedudukan Otoritas Jasa Keuangan Dalam Pengawasan Baitul Mal Wat Tamwil?

2. Bagaimana masalah yang dihadapi serta solusi atas kedudukan Otoritas Jasa Keuangan Dalam Pengawasan Baitul Mal Wat Tamwil Undang-Undang Republik Indonesia Nomor 25 Tahun 1992 Tentang Perkoperasian?

\section{METODE PENELITIAN}

\section{Metode Pendekatan}

Metode pendekatan yang digunakan dalam penelitian ini adalah yuridis normatif. Pendekatan yuridis normatif adalah pendekatan yang dilakukan berdasarkan bahan hukum utama dengan cara menelaah teori-teori, konsep-konsep, asas-asas hukum serta peraturan perundang-undangan yang berhubungan dengan penelitian ini. Pendekatan ini dikenal pula dengan pendekatan kepustakaan, yakni dengan mempelajari buku-buku, peraturan perundang-undangan dan dokumen lain yang berhubungan dengan penelitian ini.

Penelitian ini menggunakan pendekatan perundang-undangan (statute aproach) dan pendekatan kasus (case aproach). Pendekatan perundangundangan digunakan untuk mengetahui keseluruhan peraturan hukum khususnya hukum pidana di Indonesia. Pendekatan kasus bertujuan untuk mepelajari penerapan norma-norma atau kaidah hukum yang dilakukan dalam praktik hukum ${ }^{4}$.

\section{Spesifikasi penelitian}

\footnotetext{
4 Johnny Ibrahim, 2006, Teori dan Metodologi Penelitian Hukum Normatif, Malang: Bayumedia Publishing, hlm. 295
} 
e-ISSN : $2621-4105$

Spesifikasi yang digunakan adalah spesifikasi penelitian deskriptif analisis yaitu suatu penelitian yang bertujuan untuk memberikan gambaran atau penjelasan secara konkrit tentang keadaan objek atau masalah yang diteliti tanpa mengambil kesimpulan secara umum. Spesifikasi penelitian deskriptif oleh Soerjono Soekanto dalam bukunya Pengantar Penelitian Hukum dijelaskan bahwa Penelitian deskriptif adalah suatu penelitian yang dimaksudkan untuk memberikan data yang seteliti mungkin dengan manusia, keadaan atau gejala-gejala lainnya, serta hanya menjelaskan keadaan objek masalahnya tanpa bermaksud mengambil kesimpulan yang berlaku umum. ${ }^{5}$

\section{Sumber dan jenis data}

Sumber data dalam penelitian ini adalah data sekunder. Data sekunder diperoleh dari penelusuran dokumen dan kepustakaan yang berkaitan dengan perumusan masalah yang diteliti dengan tujuan untuk melengkapi, mendukung, dan memperkaya sumber data primer yang berkaitan dengan fokus penelitian. Data sekunder terdiri data bahan hukum primer, bahan hukum sekunder dan bahan hukum tertier.

\section{Teknik Pengumpulan Data}

Data sekunder terdiri data bahan hukum primer, bahan hukum sekunder dan bahan hukum tertier.

1. Bahan hukum primer, yaitu bahan-bahan hukum yang mengikat. Bahan hukum primer yang digunakan dalam penelitian ini terdiri dari peraturan perundangundangan

2. Bahan hukum sekunder, yang memberikan penjelasan mengenai bahan hukum primer, seperti, rancangan undang-undang, hasil-hasil penelitian, hasil karya dari kalangan hukum, dan seterusnya.

\footnotetext{
${ }^{5}$ Soerjono Soekanto, 1981, Pengantar Penelitian Hukum, Jakarta: UI Press, hlm. 10
} 
e-ISSN : $2621-4105$

3. Bahan hukum tertier, yakni bahan yang memberikan petunjuk maupun penjelasan terhadap hukum primer dan sekunder; contohnya adalah kamus, ensiklopedia, indeks kumulatif dan seterusnya.

\section{Teknik Analisis Data}

Teknik analisa data yang digunakan dalam penelitian ini adalah teknik analis deskriptif kualitatif, untuk kemudian dianalisis lebih lanjut sampai menjadi sebuah kesimpulan umum. Melalui pendekatan ini akan dipaparkan terlebih dahulu kondisi di lapangan yang kemudian akan dianalisis dan diteliti sebagai suatu kesatuan yang utuh. Bahan lapangan maupun data sekunder dikumpulkan untuk kemudian diseleksi, dipilahpilah berdasarkan kebutuhan serta relevansi terhadap kebutuhan yang kemudian dipergunakan dalam menjawab permasalahan.

\section{PEMBAHASAN}

\section{Tinjauan Umum}

\section{a. Otoritas Jasa Keuangan}

Dalam Undang-Undang Republik Indonesia Nomor 21 Tahun 2011 Tentang Otoritas Jasa Keuangan pasal 1 ayat 1 dinyatakan bahwa Otoritas Jasa Keuangan, yang selanjutnya disingkat OJK, adalah lembaga yang independen dan bebas dari campur tangan pihak lain, yang mempunyai fungsi, tugas, dan wewenang pengaturan, pengawasan, pemeriksaan, dan penyidikan sebagaimana dimaksud dalam UndangUndang ini.

Disini dapat ditegaskan bahwa otoritas Jasa Keuangan yang merupakan otoritas tunggal di sektor jasa keuangan di Indonesia, Otoritas Jasa Keuangan adalah sebuah lembaga pengawas jasa keuangan seperti industri perbankan, pasar modal, reksadana, perusahaan pembiayaan, dana pensiun dan asuransi yang sudah harus terbentuk pada tahun 2010. Keberadaan Otoritas Jasa Keuangan (OJK) ini sebagai suatu lembaga pengawas sektor keuangan di Indonesia perlu untuk diperhatikan, karena harus dipersiapkan dengan baik segala hal untuk mendukung keberadaan OJK tersebut. 
Dengan kata lain, dapat diartikan bahwa Otoritas Jasa Keuangan adalah sebuah lembaga pengawasan jasa keuangan seperti industri perbankan, pasar modal, reksadana, perusahaan pembiayaan, dana pensiun dan asuransi. Pada dasarnya UU tentang OJK ini hanya mengatur mengenai pengorganisasian dan tata pelaksanaan kegiatan keuangan dari lembaga yang memiliki kekuasaan didalam pengaturan dan pengawasan terhadap sektor jasa keuangan. Oleh karena itu, dengan dibentuknya OJK diharapkan dapat mencapai mekanisme koordinasi yang lebih efektif didalam penanganan masalah-masalah yang timbul didalam sistem keuangan. Dengan demikian dapat lebih menjamin tercapainya stabilitas sistem keuangan dan adanya pengaturan dan pengawasan yang lebih terintegras. ${ }^{6}$

\section{b. Pengawasan Keuangan}

Dalam bahasa Indonesia yang dimaksud dengan pengawasan adalah penilikan dan penjagaan, penilikan dan pengarahan kebijakan jalannya perusahaan. ${ }^{7}$ Controlling, pengawasan adalah upaya agar sesuatu dilaksanakan sesuai dengan peraturan yang telah ditetapkan dan instruksi dan yang telah dikeluarkan. Dilihat dari sisi yang lebih longgar pengawasan dalam arti pengawasan manajerial, adalah kegiatan untuk menjamin bahwa pelaksanaan sesuai dengan rencana. Pengawasan tersebut merupakan salah satu fungsi dalam proses manajemen yang mencakup penafsiran dan pengembangan standar pelaksanaan, pengukuran pelaksanaan yang sebenarnya, penilaian pelaksanaan dan tindakan perbaikan bila mana pelaksanaan berbeda dengan rencana. ${ }^{8}$

\footnotetext{
${ }^{6}$ Rebekka Dosma Sinaga, Sistem Koordinasi Antara Bank Indonesia Dan Otoritas Jasakeuangan Dalam Pengawasan Bank Setelah Lahirnya Undang-Undang Nomor 21 Tahun 2011 Tentang Otoritas Jasa Keuangan, Jurnal Hukum Ekonomi Universitas Sumatera Utara, 2013, hlm.2.

7 Tim Penyusun Kamus Pusat Pembinaan dan Pengembangan Bahasa, Kamus Besar Bahasa Indonesia, Balai Pustaka: Jakarta, Cet.ke-3, 1990, hlm. 58

${ }^{8}$ Komarudian, Enxiklopedia Manajemen, Bumi Aksara: Jakarta, 1994, hlm 165
} 
Pengawasan Bank pada prinsipnya terbagi atas dua jenis, yaitu pengawasan dalam rangka mendorong Bank-Bank untuk ikut menunjang pertumbuhan ekonomi dan menjaga kestabilan moneter (macro-economic supervision), dan pengawasan yang mendorong agar Bank secara individual tetap sehat serta mampu memelihara kepentingan masyarakat dengan baik (prudential supervision). ${ }^{9}$

Pengawasan merupakan salah satu fungsi dasar manajemen. Pengawasan merupakan aspek penting untuk mewujudkan tata kelola pemerintahan yang baik (good governance), yakni untuk memastikan dapat berjalan atau tidaknya fungsi pemerintahan sebagaimana seharusnya. Dikaitkan dengan akuntabilitas publik, pengawasan merupakan cara menjaga legitimasi rakyat terhadap kinerja pemerintahan. Caranya dengan membentuk sistem pengawasan yang efektif, yakni berupa pengawasan intern (internal control) dan pengawasan ekstern (external control). Selain itu, pengawasan masyarakat perlu didorong agar good governance tersebut dapat terwujud ${ }^{10}$.

\section{c. Baitul Mall Wattamwil}

BMT adalah organisasi bisnis yang juga berperan sosial. Peran BMT akan terlihat pada definisi baitul maal, sedangkan peran bisnis BMT terlihat pada definisi Baitul tamwil sebagai lembaga sosial, baitul maal memiliki kesamaan fungsi dan peran dengan Lembaga Amil Zakat (LAZ), oleh karenanya, baitul maal ini harus di dorong agar mampu berperan secara profesional menjadi LAZ yang mapan. Fungsi tersebut paling tidak upaya pengumpulan dana zakat, infaq, sedekah, wakaf dan sumber-sumber dana sosial yang lain dan upaya pentasyafuran zakat golongan yang paling berhak sesuai dengan ketentuan Undang-Undang Nomor 38 tahun 1999. Sebagai

${ }^{9}$ Adrian Sutedi, Pasar modal syariah: sarana investasi keuangan berdasarkan prinsip syariah, Sinar Grafika, 2011, hal 144

${ }^{10}$ Ahmad Fikri Hadin, 2013, Eksistensi Badan Pengawasan Keuangan dan Pembangunan di Era Otonomi Daerah, Yogyakarta, Genta Press, hlm. 21-22 
$e-I S S N: 2621-4105$

lembaga bisnis, BMT lebih mengembangkan usahanya pada sektor keuangan, yakni simpan pinjam. Usaha ini seperti usaha perbankan yaitu menghimpun dana anggota dan calon anggota (nasabah) serta menyalurkan kepada sektor ekonomi yang halal dan menguntungkan. ${ }^{11}$

Baitul maal wattamwil ( BMT ) terdiri dari dua istilah, yaitu baitul maal dan baitul tamwil.Baitul maal lebih mengarah pada usaha usaha pengumpulan dan penyaluran dana yang non profit, seperti :zakat, infaq, dan shodaqoh. Sedangkan baitul tamwil sebagai pengumpulan dan penyaluran dana komersial. Menurut Undangundang Nomor 7 tahun 1992 tentang perbankan bank adalah badan usaha yang menghimpun dana dari masyarakat dalam bentuk simpanan dan menyalurkannya kepada masyarakat dalam rangka meningkatkan taraf hidup rakyat banyak.

Sifat usaha BMT berorientasi pada (bisnis oriented) dimaksudkan supaya pengelolaan BMT dapat di jalankan secara profesional, sehingga mencapai tingkat efisiensi tertinggi. Aspek bisnis BMT menjadi kunci sukses mengembangkan BMT, dari sinilah BMT akan mampu memberikan bagi hasil yang kompetitif kepada para deposannya serta mampu meningkatkan kesejahteraan para pengelolanya sejajar dengan lembaga lain. ${ }^{12}$

\section{Kedudukan Otoritas Jasa Keuangan Dalam Pengawasan Baitul Mal Wat Tamwil}

Otoritas Jasa Keuangan yang merupakan otoritas tunggal di sektor jasa keuangan di Indonesia, Otoritas Jasa Keuangan adalah sebuah lembaga pengawas jasa keuangan seperti industri perbankan, pasar modal, reksadana, perusahaan pembiayaan, dana pensiun dan asuransi yang sudah harus terbentuk pada tahun 2010. Keberadaan Otoritas Jasa Keuangan (OJK) ini sebagai suatu lembaga hlm. 126 .

${ }^{11}$ Muhammad Ridwan, Manajemen Baitul Maal Wat Tamwil, (Yogyakarta: UII Press, 2004),

${ }^{12}$ Ibid, hlm. 129 
pengawas sektor keuangan di Indonesia perlu untuk diperhatikan, karena harus dipersiapkan dengan baik segala hal untuk mendukung keberadaan OJK tersebut.

Lahirnya Undang-Undang Nomor 21 Tahun 2011 tentang Otoritas Jasa Keuangan, pengawasan di sektor jasa keuangan di Indonesia berubah yang pada awalnya dilakukan oleh beberapa lembaga, yaitu pengawasan perbankan oleh Bank Indonesia, pengawasan pasar modal dan lembaga keuangan lainnya dilakukan olehBadan Pengawas Pasar Modal (BAPEPAM) dan Lembaga Keuangan menjadi pengawasan yang dilakukan oleh lembaga tunggal, yaitu Otoritas Jasa Keuangan. Berdasarkan Pasal 1 angka 1 Undang-Undang No 21 tahun 2011 menyatakan bahwa Otoritas Jasa Keuangan adalah lembaga yang independen bebas dari campur tangan pihak lain, yang mempunyai fungsi, tugas dan wewenang pengaturan, pemeriksaan dan penyidikan di sektor perbankan, pasar modal, perasuransian, dana pensiun, lembaga pembiayaan dan lembaga jasa keuangan lainnya.

Secara teoritis, terdapat dua aliran (school of thought) dalam hal pengawasan lembaga keuangan. Di satu pihak terdapat aliran yang mengatakan bahwa pengawasan industri keuangan sebaiknya dilakukan oleh institusi tunggal. Di pihak lain ada aliran yang berpendapat pengawasan industri keuangan lebih tepat apabila dilakukan oleh beberapa lembaga.

Sesuai dengan amanah ketentuan peralihan Undang-Undang No. 21 Tahun 2011 tentang OJK, sejak tanggal 31 Desember 2012, fungsi, tugas, dan wewenang pengaturan dan pengawasan kegiatan jasa keuangan di sektor Lembaga Pembiayaan beralih dari Menteri Keuangan dan Bapepam LK kepada OJK. Walaupun demikian, teknis pengawasan masih mengikut kepada peraturan menteri tersebut. Pengawasan terhadap perusahaan modal ventura dibagi menjadi 
tiga tahapan: praoperasional usaha, saat operasional usaha, dan pasca operasional usaha $^{13}$.

\section{Permasalahan Yang Dihadapi Serta Solusi Atas Kedudukan Otoritas Jasa} Keuangan Dalam Pengawasan Baitul Mal Wat Tamwil Undang-Undang Republik Indonesia Nomor 25 Tahun 1992 Tentang Perkoperasian

Lembaga keuangan di Indonesia secara umum dibagi menjadi dua, yaitu lembaga keuangan bank dan lembaga keuangan nonbank. Lembaga keuangan bank meliputi bank umum, bank syariah, dan Bank Perkreditan Rakyat (umum dan syariah). Lembaga keuangan nonbank meliputi perasuransian, pasar modal, perusahaan pegadaian, dana pensiun, koperasi, dan lembaga penjaminan dan pembiayaan-perusahaan yang dapat dikategorikan sebagai lembaga pembiayaan antara lain perusahaan sewa guna usaha (leasing), perusahaan pembiayaan konsumen, dan perusahaan modal ventura.45 Regulasi dan supervisi terhadap lembaga keuangan bank dan nonbank selama ini ditangani oleh institusi yang berbeda. Lembaga keuangan bank diatur dan diawasi oleh Bank Indonesia (BI), sedangkan lembaga keuangan nonbank seluruhnya diawasi oleh Bapepam-LK sebuah lembaga yang bernaung di bawah Kementerian Keuangan. Regulasi dan supervisi sektor perbankan dilaksanakan oleh Bank Indonesia berdasarkan amanat UU BI. Sektor perbankan diatur dan diawasi oleh BI karena sektor tersebut memiliki pertautan erat dengan kebijakan moneter mengawasi dan mengatur sektor perbankan merupakan salah satu tugas untuk mencapai kestabilan nilai tukar rupiah.

Hal inilah yang menjadi kendala teknis peran OJK dalam melakukan pengawasan terhadap lembaga keuangan non bank. Pengawasan yang tercakup dalam tugas Otoritas Jasa Keuangan (OJK) tidak termasuk pada lembaga keuangan berbentuk koperasi, lembaga keuangan mikro, dan Baitul Mal Wa

${ }^{13}$ Mireza Fitriadi, 2014, Kedudukan Hukum Perusahaan Modal Ventura Asing dalam Melakukan Pembiayaan secara Langsung di Indonesia, Skripsi, Fakultas Hukum Universitas Gadjah Mada, Yogyakarta, hlm. 25. 
e-ISSN : 2621-4105

Tamwil (lembaga keuangan berbasis syariah). OJK hanya ditugasi untuk mengawasi bank, bank perkreditan rakyat, dan lembaga keuangan bukan bank.

Dalam praktik yang demikian, yang memungkinkan terjadinya kekosongan pengawasan keuangan pada koperasi, BMT, dan lembaga keuangan mikro memiliki potensi masalah. Dengan terpisahnya istitusi pengawasan tersebut, sudah dapat dipastikan tidak ada jaringan komunikasi yang mapan antara OJK dengan Kementerian Koperasi dan UKM, serta BMT dan lembaga keuangan mikro.

Padahal untuk menjalankan operasionalnya strategi pemasaran tidak hanya dibutuhkan oleh perbankan saja. Namun BMT sebagai lembaga keuangan mikro juga penting akan adanya strategi pemasaran yang dimiliki untuk kelangsungan hidup BMT. Secara konsep memang BMT menghendaki adanya bebas riba dan juga penerapan strategi pemasarannya dengan sesuai syariah sehingga terciptanya keadilan. Hal demikian mengharuskan manajemen melakukan strategi khusus untuk mempertahankan keunggulan kompetitif yakni merujuk pada kemampuan sebuah organisasi untuk memformulasikan strategi yang menempatkannya pada suatu posisi yang menguntungkan berkaitan dengan perusahaan lainnya. Keunggulan kompetitif juga berarti kumpulan strategi untuk menentukan keunggulan suatu perusahaan dari persaingan diantara perusahaan yang lain ${ }^{14}$. Oleh kerenanya pengawasan secara independent melalui kelembagaan seperti OJK sangat dibutuhkan oleh BMT dalam menjalankan aktifitas-aktifitas keuangan.

Konstruksi secara teori adanya pengawasan yang lemah bisa ditinjau dari teori keberlakuan hukum. Menurut Lawrence Friedman, unsur-unsur sistem hukum itu terdiri dari struktur hukum (legal structure), substansi hukum (legal

${ }^{14}$ David Hunger dan Thomas Wheelen,(2003) Manajemen Strategis, Yogyakarta: Penerbit Andi, Hal. 16. 
substance) dan budaya hukum (legal culture). ${ }^{15}$ Lawrence Friedman. Friedman membagi sistem hukum dalam tiga (3) komponen memberikan penjelasan yaitu: ${ }^{16}$ 1. Substansi hukum (substance rule of the law), di dalamnya melingkupi seluruh aturan baik yang tertulis maupun yang tidak tertulis, baik yang hukum material maupun hukum formal.

2. Struktur hukum (structure of the law), melingkupi Pranata hukum, Aparatur hukum dan sistem penegakkan hukum. Struktur hukum erat kaitannya dengan sistem peradilan yang dilaksanakan oleh aparat penegak hukum, dalam sistem peradilan pidana, aplikasi penegakan hukum dilakukan oleh penyidik, penuntut, hakim dan advokat.

3. Budaya hukum (legal culture), merupakan penekanan dari sisi budaya secara umum, kebiasaan-kebiasaan, opini-opini, cara bertindak dan berpikir, yang mengarahkan kekuatan sosial dalam masyarakat.

Struktur hukum sendiri menempati posisi strategis yang meliputi badan eksekutif, legislatif dan yudikatif serta lembaga-lembaga terkait, seperti Kejaksaan, Kepolisian, Pengadilan, Komisi Judisial, Komisi Pemberantasan Korupsi (KPK) dan lain-lain. Struktur Hukum adalah keseluruhan institusi penegakan hukum beserta aparatnya yang mencakup kepolisian dengan para polisinya, kejaksaan dengan para jaksanya, kantor pengacara dengan pengacaranya, dan pengadilan dengan hakimnya. Substansi Hukum adalah keseluruhan asas hukum, norma hukum dan aturan hukum baik yang tertulis maupun yang tidak tertulis. Kultur hukum adalah kebiasaankebiasaan, opini-opini, cara berpikir, dan cara bertindak baik dari penegak hukum maupun dari warga masyarakat. ${ }^{17}$ Hal ini juga ditegaskan oleh sudikno, bahwa komponen struktur

${ }^{15}$ Lawrence Friedman, “American Law”, (London: W.W. Norton \& Company, 1984), hal. 6.

${ }^{16}$ Lawrence M. Friedman; The Legal System; A Social Scince Prespective, Russel Sage Foundation, New York, 1975; hlm. 12 - 16.

${ }^{17}$ Ahmad Ali, Menguak Teori Hukum (Legal Theory) dan Teori Peradilan (Judicialprudence) Termasuk Interpretasi Undang-Undang (Legisprudence), Volume 1 Pemahaman Awal, Kencana, Jakarta, 2009, hlm. 204 
hukum dalam sistem hukum Indonesia dalam lingkup penegakan hukum diatur dalam UU No. 8 Tahun 1981 yang meliputi; mulai dari Kepolisian, Kejaksaan, Pengadilan dan Badan Pelaksana Pidana (Lapas).

Kewenangan lembaga penegak hukum tersebut dijamin oleh undang-undang, oleh karenanya dalam melaksanakan tugas dan tanggung jawabnya, para penegak hukum harus terlepas dari intervensi lembaga eksekutif dan pengaruh eksternal lainnya. Terdapat adagium yang menyatakan meskipun dunia ini runtuh hukum harus ditegakkan. Hukum tidak dapat berjalan atau tegak bila tidak ada aparat penegak hukum yang kredibel, kompeten dan independen. Seberapa bagusnya suatu peraturan perundang-undangan bila tidak didukung dengan aparat penegak hukum yang baik maka keadilan hanya angan-angan. Pengadilan dalam struktur hukum diantaranya menjalankan fungsi penegakan hukum. Dalam menegakkan hukum ini ada tiga hal yang harus diperhatikan, yaitu kepastian hukum, kemanfaatan dan keadilan. ${ }^{18}$

\section{E. PENUTUP}

Kedudukan OJK diorientasikan dengan tujuan Meningkatkan dan memelihara kepercayaan public di bidang jasa keuangan, menegakkan peraturan perundangundangan di bidang jasa keuangan, meningkatkan pemahaman public mengenai bidang jasa keuangan; dan Melindungi kepentingan konsumen jasa keuangan. Jika sesuai dengan Pasal 4 UU OJK, Otoritas Jasa Keuangan dibentuk agar keseluruhan kegiatan jasa keuangan di sektor jasa keuangan mulai dari terselenggara secara teratur, adil, transparan dan akuntabel, Serta mampu mewujudkan system keuangan yang tumbuh secara berkelanjutan dan stabil; dan Mampu melindungi kepentingan konsumen dan masyarakat menjadi peranan penting bagaimana subtansi kewenangan atas OJK sebagai pengawas jasa keuangan bisa diperankan dengan baik. Salah satu komponen penting dalam sistem perekonomian nasional dimaksud adalah sistem keuangan dan seluruh kegiatan jasa keuangan yang menjalankan

\footnotetext{
${ }^{18}$ Sudikno Mertokusumo, Mengenal Hukum, Liberty: Yogyakarta, 1986, hal. 130.
} 
fungsi intermediasi bagi berbagai kegiatan produktif di dalam perekonomian nasional. Pola dan mekanisme yang dilakukan otoritas jasa keuangan pada lembaga keuangan mikro sangat lemah karena Fungsi pengawasan sebatas koordinasi, dan berkenaan dengan kegiatan usaha yang berdasarkan prinsip pun demikian. Kewenangan utama yang diberikan kepada Dinas Koperasi sebagai bagian dari Kementrian Koperasi dan UMK selama ini sudah cukup sibuk dengan mengurusi koperasi-koperasi yang tidak sehat secara modal dan keuangan, belum menyentuh koperasi yang tidak sehat secara kepatuhan syariah. Padahal setiap dinas koperasi telah membentuk pejabat pengawas yang khusus mengawasi lembga mikro terutama BMT. Hal ini yang menyebabkan mekanisme pengawasan pada koperasi BMT menjadi lemah, karena minimnya usaha dari dinas koperasi. kewenangan OJK melakukan pengawasan lebih esensial dibanding lembaga lain adalah bahwa OJK menjalankan perananya sesuai dengan ketentuan yang ada dan secara kelembagaan, Otoritas Jasa Keuangan berada di luar Pemerintah, yang dimaknai bahwa Otoritas Jasa Keuangan tidak menjadi bagian dari kekuasaan Pemerintah. Namun, tidak menutup kemungkinan adanya unsur-unsur perwakilan Pemerintah karena pada hakikatnya Perubahan regulasi bahwa OJK dapat menjalankan peran sebagai lembaga pengawas tentunya sangat penting untuk dilakukan. Selain itu harmonisasi peraturan untuk mengarahkan OJK sebagai salah satu lembaga independent pengawas Jasa keuangan sangat dibutuhkan agar dikemudian hari posisi OJK dapat menjadi kontribusi nyata pada pelaksanaan sistem keuangan pada BMT.

\section{DAFTAR PUSTAKA}

\section{BUKU}

Achmad Ali, 2010, Menguak Teori Hukum (Legal Theory) \& Teori Peradilan (Judicialprudence) Termasuk Undang-Undang (Legisprudence) Volume I Pemahaman Awal, Kencana Prenada Media Group, Jakarta

Adrian Sutedi, Aspek Hukum Otoritas Jasa Keuangan (Jakarta: Penebaran Swadaya Group, 2014) 
Adrian Sutedi, Pasar Modal Syariah: Sarana Investasi Keuangan Berdasarkan Prinsip Syariah, Sinar Grafika, 2011

Ahmad Fikri Hadin, 2013, Eksistensi Badan Pengawasan Keuangan dan Pembangunan di Era Otonomi Daerah, Yogyakarta, Genta Press

Buchari Alma, Manajemen Bisnis Syari'ah, (Bandung: IKAPI, 2009)

David Hunger dan Thomas Wheelen,(2003) Manajemen Strategis, Yogyakarta: Penerbit Andi

Hermansyah, Hukum Perbankan Nasional Indonesia (Jakarta, Kencana Prenada Media Group, cet-1 Mei 2005)

Johnny Ibrahim, 2006, Teori dan Metodologi Penelitian Hukum Normatif, Malang: Bayumedia Publishing

Kasmir, Bank dan Lembaga Keuangan lainnya, PT.Raja Grafindo Persada, Jakarta, 2011

Komarudian, Enxiklopedia Manajemen, Bumi Aksara: Jakarta, 1994

Lawrence Friedman, "American Law", (London: W.W. Norton \& Company, 1984)

Lawrence M. Friedman; The Legal System; A Social Scince Prespective, Russel Sage Foundation, New York, 1975

Muhammad Ridwan, Manajemen Baitul Maal Wat Tamwil, (Yogyakarta: UII Press, 2004)

Peter Mahmud Marzuki, 2008, Pengantar Ilmu Hukum, Kencana Prenada Media Group, Jakarta, (selanjutnya di singkat Marzuki I)

Rebekka Dosma Sinaga, Sistem Koordinasi Antara Bank Indonesia Dan Otoritas Jasakeuangan Dalam Pengawasan Bank Setelah Lahirnya Undang-Undang Nomor 21 Tahun 2011 Tentang Otoritas Jasa Keuangan, Jurnal Hukum Ekonomi Universitas Sumatera Utara, 2013

Ryan Filbert Wijaya, Negative Investment: Kiat Menghindari Kejahatan dalam Dunia Investasi (Jakarta: PT. Elex Media Komputindo, 2014)

Soerjono Soekanto, 1981, Pengantar Penelitian Hukum, Jakarta: UI Press

Sudikno Mertokusumo, Mengenal Hukum, Liberty: Yogyakarta, 1986

Tim Penyusun Kamus Pusat Pembinaan dan Pengembangan Bahasa, Kamus

Besar Bahasa Indonesia, Balai Pustaka: Jakarta, Cet.ke-3, 1990

\section{JURNAL}

Afika Yumya Syahmi, Pengaruh Pembentukan Pengawasan Lembaga Perbankan Suatu Kajian Terhadap Undang-Undang Otoritas Jasa Keuangan, Skripsi Sarjana, Fakultas Hukum Universitas Indonesia, Depok, 2004

Mireza Fitriadi, 2014, Kedudukan Hukum Perusahaan Modal Ventura Asing dalam Melakukan Pembiayaan secara Langsung di Indonesia, Skripsi, Fakultas Hukum Universitas Gadjah Mada, Yogyakarta 
Novita Dewi Mashyitoh, Analisis Normatif Undang-Undang No. 1 Tahun 2013 Tentang Lembaga Keuangan Mikro (Lkm) Atas Status Badan Hukum Dan Pengawasan Baitul Maal Wat Tamwil (BMT), Jurnal E-Conomica, Volume V/Edisi 2/Oktober 2014

Zainal Arifin Mochtar dan Iwan Satriawan, Jurnal Konstitusi, Volume 6, Nomor 3, September 2012

Zulkarnain Sitompul, "Fungsi dan Tugas Otoritas Jasa Keuangan dalam menjaga stabilitas Sistem Keuangan," (Medan:disampaikan pada Seminar tentang Keberadaan Otoritas Jasa Keuangan untuk Mewujudkan Perkonomian Nasional yang Berkelanjutan dan Stabil, 25 November 2014)

\section{UNDANG-UNDANG}

Undang-Undang dasar negara Republik Indonesia 1945

Undang-Undang Republik Indonesia Nomor 25 Tahun 1992 Tentang Perkoperasian

Undang-Undang No. 17 Tahun 2012 tentang Perkoperasian

Undang-Undang Republik Indonesia Nomor 21 Tahun 2011 Tentang Otoritas Jasa Keuangan

\section{INTERNET}

http://www.ojk.go.id/siaran-

pers-aturan-pelaksanaan-

pungutan-ojk (diakses tanggal 8

Februari 2018 pukul 12.00

WIB)

https://id.wikipedia.org/wiki/B

aitul_Maal_wa_Tamwil,

diunduh pada 12 November

2017 